Article

\title{
Electoral cycles, stock market volatility and exchange rate: The indissoluble trivet
}

\author{
Sharlywest Uwabor Eboigbe ${ }^{1 *}$, and Victor Usunobun Imagbe ${ }^{2}$ \\ 1 Department of Banking and Finance, Faculty of Management Sciences, University of Benin, Benin City, \\ Nigeria; sharlywest.eboigbe@uniben.edu \\ 2 Bursary Department, University of Benin, Benin City, Nigeria; usunobun.imagbe@uniben.edu \\ * Corresponding author.
}

Received: 6 October 2020; Accepted: 19 March 2020; Published: 7 April 2020

\begin{abstract}
This paper seeks to unravel the connectivity between stock market volatility and exchange rate within the political cycles of sovereign states presidential election years between 2000-2016 using the dynamic system GMM estimation and VECH technique data source from Morgan Stanley Capital International (MSCI). A significant positive relationship between market volatility and exchange rate manifests in the studied countries, more in Nigeria and South Africa. A significant shift in a conditional correlation of the variances of most markets exists except for Kenya, Japan, and Hong Kong. This perhaps is indicative of weak institutional and democratic culture within the financial system; hence independence of public institutions would guarantee non-interference that ensures policy consistency. Financial, economic and behavioral finance barometers need to integrate both local and international political development for effective and result-driven investment. As a result of the significant opportunistic business cycle effect that manifested with a significant shift in the conditional correlations of the variances of some of the markets we strongly believe that a truly independent central bank would not only guarantee political non-interference but also will ensure policy consistency.
\end{abstract}

Keywords: financial economics, financial market, political economy, behavioral finance, event study, volatility transmission, revealed volatility.

JEL codes: B29, D53, P16, G02, G14, C58, C51

\section{Introduction}

Variability in economic activities originating from external interference of political actors seeking to be re-elected is termed political business cycle theory. This unpredictability in activities could penetrate the financial market indicators as a result of monetary and fiscal policy interplay within an election cycle. The concept is underpinned by the assumption that there exists a short-term trade-off between the level of manpower and resource utilization as well as employment and inflation in the aggregate economy. Since political officeholders are rational actors who rank their political objectives, therefore the desire to study the effect of their action is imperative to financial economists, researchers and investors.

These cycles result from friction in the economic system outside the context of real shocks. A frictionless financial market denotes transparency where asymmetric information that drives adverse selection and moral hazard is absent. Business cycles are better explained by the traditional real business cycle theory (RBCT). RBC theory, therefore, sees business cycles as a reflection of the most efficient operation of the economy, not market failure. This is consistent with a competitive market equilibrium where economic agents are rational and behaviourally biased toward their investment 
options. The theory is further shored up by these three conventions. First, it is driven by enormous and rapid changes in product strength. Secondly, the unemployment level reveals the amount employees are willing to accept for a specific job and thirdly, monetary policy is inextricably linked with economic performances. Business cycles are either triggered by exogenous productivity distortions or shocks inflated by fundamental factors like the substitution of factors of production, changes in the supply of labor, consumption smoothing, and investment delay. Though the real business cycle occurs not instantaneous but takes time and has the same effect on dissimilar industries at the same time. This is called the market efficient response to external alterations.

As people and corporations have trade-offs so also is the consumption-investment choice as well as the labor-leisure trade-off. The study of the aggregate economy using the Real Business Cycle model foresees that during temporary shock, productivity, consumption, investment, and employment will increase above their long-term trends. Therefore business cycle rising and falling are the product of accumulation or de-accumulation of wealth, which are determined by the prevailing national politicoeconomic culture (Blomberg \& Hess, 2003). These models integrate many factors upon which economic variation hinges but fail to take cognizance of office-holders influence in the cycles powered by their quest for re-election. As an individual has a preference so also does government actors. Sometimes such preference may not be consistent with the need for the economy from time to time. These incongruences reveal electorates' low ratings after the elections. Therefore, politicians and their parties should not be trusted with market-oriented macroeconomic policies. This is due to their determination to alter institutional capacities of existing economic policies and structures to realize their short-term aim of winning elections.

The transmission of devaluation risk and alteration of interest rate and money supply due to timebound events and other exogenous factors to economic developments is disastrous. According to Fratzscher and Stracca, (2009a \& 2009b), Stein, Streb, and Ghezzi, (2005) and Cermeno, Grier and Grier, (2010), the events of essence includes political elections, the inauguration of the new administration, resignations, politically-related suicides, referenda, and politically-inspired terrorism. They aver that post-election exchange rates are unpredictable and less volatile which disappears after the events. Nevertheless, these aforementioned assertions did not go unopposed as (Frieden, Ghezzi \& Stein, 2001; Stein \& Streb 2004; Stein, Streb \& Ghezzi, 2005) find no trace of election-induced appreciation in their test for the political budget cycle in nominal exchange rates and other economic indicators. In the light of these aforesaid, attempt to establish that connectivity between stock returns volatility and exchange rate within the political cycle exist. We, therefore, seek to find the relationship between incumbent dreams of re-election impact on capital market movement and exchange rate within the event period of the selected countries. Premised on these convolutions, we hypothesized therefore that:

"There is a significant positive relationship between the Exchange rate and stock market volatility within an electoral cycle."

\section{Literature Review}

The failure of the dollar standard of the Bretton Woods of 1944 led to a change in exchange rate policy from the fixed regime to the floating regime. With the managed float regime, individual states are at liberty to intervene in the management of her foreign exchange rates through the instrumentality of the monetary policies whenever it deems appropriate. This politico-economic freedom confronts governments with a trade-off between gains from economic efficiency occasioned by monetary policy credibility and the attainment of politicians set goals on winning elections. On the other hand, monetary policy autonomy is giving to a politician to manipulate spells disaster for the nation. There is a consensus therefore that the quality of the political system and its institutions are fundamental to a country's prosperity. Sammo, Yunjong, and Yoon (2002), Frankel, Schmukler and Serven (2002) show that the adoption of the free-floating exchange rate will not insulate the economy from external currency and exchange rate volatility shock. This shock is evidenced in an export-import relationship that leads to a trade balance between trading partners. This could sometimes reduce interdependence entrenched in the monetary independence of the various national regulators. Economy disorderliness 
such as a shift in global demand resulting from politico-economic interactions of expansionary and contractionary monetary policy will be at the mercy of trading partners' absorptive capacities. This is vital restoring the equilibrium position of the nation through stimulating demand for domestic products which returns the economy to the desired levels of employment and output.

International openness in the form of trade and capital flows promotes business cycle harmonization across countries without recourse to the political structure. This harmony is enhanced by the interplay of trade and capital markets among countries nurtured by foreign portfolios investments as well as global or regional economic blocs' common shocks occasioned by foreign exchange rate disparity.

Therefore, it is a truism to say that the co-movements of the business cycles and electoral cycles fostered by the transmission of country-specific shocks to other countries reveal the absence of absolute independence of national monetary regulatory agencies. This further reinforces the chances of the opportunistic and partisanship effect on the capital market development and the various cycles within the economy (Levy-Yeyati \& Ubide, 2000 \& 2001; Kawai \& Takagi, 2001). Trade integration thus leads to business cycle synchronization amongst trading partners. Hence, a high financial asset price correlation could lead to increasing real economic activities across countries (Dalsgaard, Elmeskov \& Park, 2002). Researchers allude to the fact that local currency devaluation is one of the monetary policy tools most unlikely to be implemented in the pre-electoral period but proximately affected at the postelectoral period for the incumbent administration. Therefore, investors' knowledge of these regulatory nexuses with politics is off the essence. This consequently suggests that such expectation of postelection devaluations will certainly induce pre-election declines in investment which will result in the infractions of key economic indices (Rogoff, 1990; Frieden, Gezzi, and Stein 2001; Leblang 2003; Stein \& Streb 2004). Stein and Streb, (2004), Stein et al. (2005) submit those electoral events in Italy increase short-term interest rates, reduces equity returns and run down currency exchange rates significantly. This they aver further leads to structural disruption in the macroeconomic variables before the emergence of the European Central Bank (ECB). They, therefore, opined that ECB has insulated the general economy by severance of the monetary units from various independent domestic regulators which are subservience to political manipulations.

Also worthy of note is that the choice of a stable and growth-enhancing exchange rate regime premised on the desire to fight inflation rather than political consideration, institutional strength as well as partisanship preferences of the key players (Bernhard \& Leblang 1999; Bernhard \& Leblang 2002; Clark 2002; Keefer \& Stasavage 2002; Clark \& Hallerberg 2002). Exchange rates and money supply components of the monetary policies ought to be predictable and credible for sustained economic growth and development. This is consistent with Stasavage, 2003; Shambaugh, 2004; Genberg, \& Swoboda, 2005; Von Hagen, \& Zhou, (2005).

\subsection{Theoretical Fundamentals and Schematic Relationship between Macroeconomic Indicators.}

From the illustrations in Figure 1, it is therefore correct to say those politically induced and selfishly articulated policies have ways of impacting negatively on the aggregate economic index. Here, the political players in connivance with different agencies within and outside the government could reinvent the wheel of efficient market forces driven economy.

From Figure 1, it is evident that endogenously and exogenously induced policies ultimately transmit its respective intent to the event or time-bound targets of the government.

This exists where the politicians handling the fiscal tools and their connected allies in the monetary units subtly consent to the short-term objective of the political party and head of government on the local front. As the local endogenous manipulation harmonizes with perceived international partners through Grants and Aid, favorable rating agencies report, etc. Symbolically, the above is thus represented as $\mathrm{A} 1+\mathrm{A} 2=\mathrm{C} ; \mathrm{A} 1+\mathrm{A} 2+\mathrm{A} 3=\mathrm{B} ; \mathrm{C}+\mathrm{B}=\mathrm{D}$ OR B $=\mathrm{D}$ (Time-bound targets). 




Figure 1: Schematic Relationship of Macroeconomic Indicators.

Figure 2 shows the various endogenous components to the political shenanigans targeted at the electorates with decay and short memories whose interest is the economy as of today.

Figure 3 denotes the development of events before an election to after the election. The tendencies for each of these elements to impact the aggregate economic indicators appears to be a function of the strength of the national institution, the depth and breadth of their financial markets as well as the political consciousness of the electorates. Also of the essence in the direction of the various international interventionist schemes like Aid and Grants from donor agencies within the electoral cycles. Premised on these convolutions, we hypothesized therefore that:

\section{Data and Methods}

The transmission of volatility from the exchange rate to the stock market within electoral cycles has been verified using information flows through several financial variables (Clark 1973; Goonatilake \& Herath, 2007; Simmons \& Hainmueller, 2008; Sayce, 2013). Engle (1982) and Bollerslev (1986) ARCH model as the most commonly used method for demonstrating the volatility of financial time series data was adopted. Hays et al 2000, Hays, Freeman and Nesseth 2003, Bialkowoki et al 2008, Mensi, Beljid, Boubaker, and Managi, (2013) approach to the Bi-Variate GARCH model was applied in estimating the interdependence of the conditional changes, volatility, and connections amongst these variables. This also dovetailed nicely with the VECH model of Bollerslev, Baillie, and DeGennaro, (1990) where the relationship between systems shock presumed to be constant is adopted for ease and robustness of the analysis. 


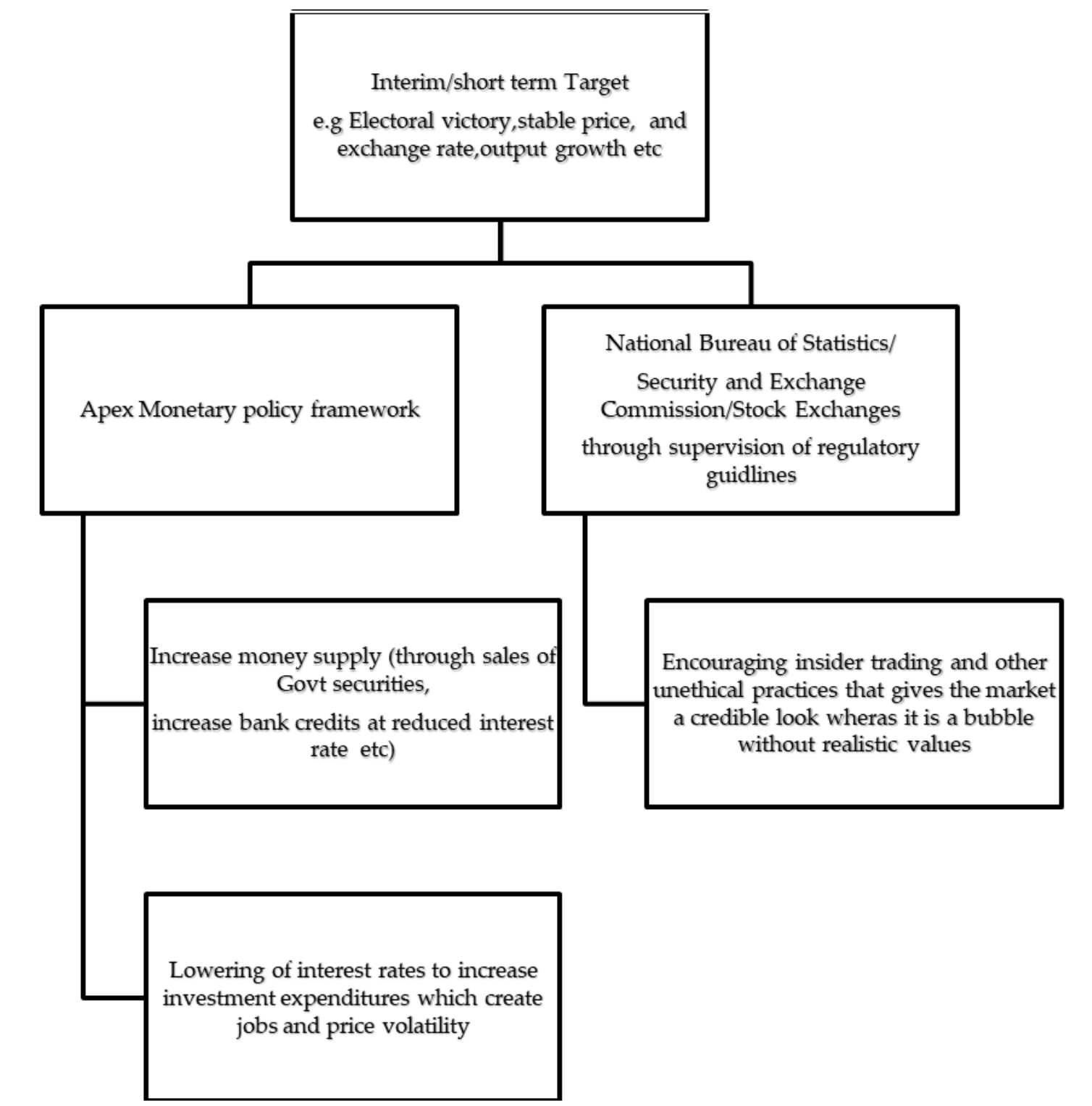

Figure 2: Schematic Relationship of Macroeconomic Indicators
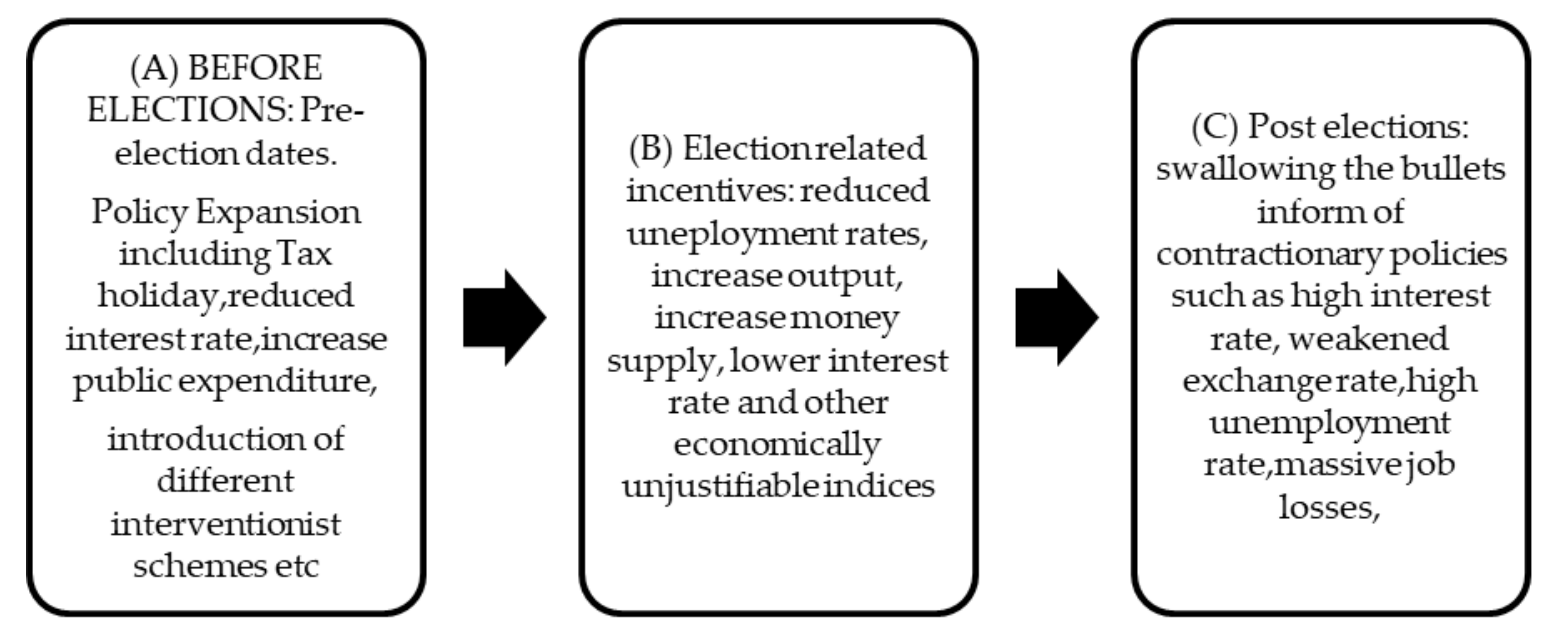

Figure 3: Schematic representation of this study 
The equation of the bivariate GARCH $(1,1)$ is as decomposed below:

$$
\begin{aligned}
Y_{t} & =c+\Phi T_{t-1}+\varepsilon t \\
\varepsilon t & =h_{-} t^{\wedge} \square(1 / 2) \eta_{-} t
\end{aligned}
$$

where: Yt $=($ EXRTVt, SVM $)$, in which EXRTV represents exchange rate volatility and SMV is stock market volatility defined in time $t$.

$\varepsilon t=\left(\left(\varepsilon_{-} t^{\wedge} \operatorname{exrtv}, \varepsilon_{-} t^{\wedge} \operatorname{smv}\right)\right.$, where $\varepsilon_{-} t^{\wedge} \operatorname{exrtv}$ and $\varepsilon_{-} t^{\wedge} \operatorname{smv}$ are the residuals of the averaged equations for real exchange rate and oil price volatility respectively.

$\eta_{-} t=\llbracket(\eta]_{-} t^{\wedge}$ exrtv, $\left.\eta_{-} t^{\wedge} s m v\right)$, refers to the innovation that is independent, identically distributed random vector (see Mensi, et al 2013).

$h_{-} t^{\wedge} \square(1 / 2)$ is a diagonal matrix containing the conditional adjustments of exrtvt and smvt in that order, which can be symbolized as( $\square_{-} \mathrm{t}^{\wedge}($ exrtv)$\left.), \mathrm{h}_{-} \mathrm{t}^{\wedge} \mathrm{smv}\right)$. Therefore, as a result of VECH analysis, the connected adjustment equations for these variables are:

$$
\begin{aligned}
& h_{t}^{\text {exrtv }}=C_{\text {exrtv }}+\alpha_{\text {exrtv }}\left(\varepsilon_{t-1}^{\text {exrtv }}\right)^{2}+\beta_{\text {exrtv }} h_{t-1}^{\text {exrtv }}+\alpha_{s m v}\left(\varepsilon_{t-1}^{s m v}\right)^{2}+\beta_{\text {smv }} h_{t-1}^{\text {smv }} \\
& h_{t}^{\text {smv }}=C_{\text {smv }}+\alpha_{\text {smv }}\left(\varepsilon_{t-1}^{\text {smv }}\right)^{2}+\beta_{s m v} h_{t-1}^{\text {smv }}+\alpha_{\text {exrtv }}\left(\varepsilon_{t-1}^{\text {exrtv }}\right)^{2}+\beta_{\text {exrtv }} h_{t-1}^{\text {exrtv }}
\end{aligned}
$$

Equations: (3) and (4) shows how volatility diffused across exchange rate and stock market instability over time. The cross value of these error terms and denotes the volatility of the stock market across the currency exchange rate at time $(\mathrm{t}-1)$. And this also represents the ARCH effect of previous shocks that captures the direct impact of shocks diffusion. The existence of and detects the instability and interrelatedness between the exchange rate and the stock market. Based on the above-decomposed model, previous shock and exchange rate volatility impact the future volatilities of the stock market.

Panel data estimation technique was adopted bearing in mind that economic variables from different economic blocks were used in the estimation (see Woodridge, 2001; Opare, 2012; Savita \& Ramesh, 2015 and Riaz, Ghulzar \& Robbani, 2015). Here, the dynamic system GMM (generalized method of moment) estimation technique becomes relevant to easily address the problem of heterogeneity and simultaneity that may exist between policy instruments and variables over time. In addition to the VECH technique adopted for the volatility transfer model, other equations in the study made use of the Ordinary Least Squares (OLS) technique. The data used were pooled together to form a panel data and were obtained from Morgan Stanley Capital International (MSCI) designed to measure equity market performance, World Bank and Trading Economics for the various presidential elections within 2000-2016. The study made used a data filtering approach in getting daily stock market data and foreign exchange rates for the countries.

Our population of interest here is independent democratic countries of the global community, with a sampled size of the study including the United Kingdom, United States of America, Japan, China, Hong Kong, Egypt, Republic of South Africa, Nigeria, Kenya, France, and Germany. This is intending to review globally the effect of political events on the capital market and national economic indices. A look at the list reveals that the countries have stable democratic culture as well as leaders in their respective economic and sub-regional groupings. They are also among the first forty largest economies as at the date of this study.

The following are the various countries politically-related events dates for the countries as indicated with the political parties in brackets. Republic of South Africa -14th April 2004 (ANC), 22nd April 2009 (ANC) and 07th May 2014 (ANC). Nigeria: 19th April 2003 (PDP), 21st April 2007 (PDP), 16th April 2011 (PDP) and 28th March 2015 (APC). Egypt: 25th May 2005 (Political Referendum), 26th March 2007 (Political Referendum), 19th March 2011 (Political Referendum), 24th May 2012 (Election/Freedom Justice Party), 03rd July 2013 (Coup) and 28th May 2014 (Independent). United Kingdom: 07th May 2000 (LP), 05th May 2005 (LP), 06th May 2010 (CP/LP) and 07th May 2015 (CP). United States of America: 07th November 2000 (Republican), 02nd November 2004 (Republican), 04th November 2008 (Democrat) and 06th November 2012 (Democrat). China: 20th March 2004 (DP), 22nd March 2008 (CNP), 14th March 2012 (CNP) and 16th March 2016 (DP). Japan: 11th September 
2005(LDP), 30th August 2009(LDP), 16th December 2012 (LDP) and 14th December 2014 (LDP). Brazil: 06th October 2002(PDT), 01st October 2005 (PDT), 3rd \&31st October 2010 (PDT) and 05th October 2014(PDT). Hong Kong: 28th February 2002 (Non-partisanship), 16th June 2005 (Non-partisanship), 25th March 2007 (Non-partisanship) and 25th March 2012(Non-partisanship). Germany:22nd September 2002 (SDP), 18th September 2005 (CDU), 27th September 2009 (CDU) and 22nd September 2013 (CDU). France: 5th -6th May 2002 (RR), 5th -6th May 2007 (UPM) and 5th -6th May 2012 (SP).

\section{Results and Discussion}

Here we use volatility estimation techniques to determine how stock market volatility tends to be transmitted into domestic exchange rate performance for the selected countries in our sample, especially within the political business cycles. This can help demonstrate the effects of stock market activities on other macroeconomic variables.

\subsection{Unit Root Test Results}

Following the nature of the investigation carried out in this section, the first step of the analysis is to check for stationarity properties of the panel data employing homogenous panel unit root tests [Levin, Lin \& Chu- LLC] and heterogeneous panel unit root tests [Im, Pesaran, and Shin-IPS], Augmented-Dickey-Fuller Fisher test (ADF), and the Phillips-Perron test-PP]. These test methods are used since the system specification of the multivariate GARCH is used for the analysis with test results presented in Table 1. A time series is stated as non-stationary if mean and variance of the time series are dependent over time (Gujarati, Porter \& Gunasekar, 2009). Conversely, a time series is stated as stationary if the mean and variance are constant over time. Most economic time series are nonstationary and only achieve stationary at the first difference level or a higher level. The importance of stationarity of time series used in regression borders on the fact that a non-stationary time series cannot be generalized to other periods apart from the present. This makes forecasting based on such time series to be of little practical value. Moreover, regression of a non-stationary time series on another non-stationary time series may produce a spurious result.

Table 1. Unit Roots Tests Results

\begin{tabular}{|c|c|c|c|c|c|c|c|c|c|c|}
\hline & UK & US & RSA & Nigeria & $\mathbf{H}-\mathbf{K}$ & China & Kenya & Japan & France & Germany \\
\hline \multicolumn{11}{|c|}{ Null: unit root (assumes a common unit root process) Levels test } \\
\hline LLC & 1.02 & 0.64 & 1.62 & 0.27 & $-2.77^{*}$ & 0.84 & 0.09 & -0.32 & -0.27 & 0.71 \\
\hline \multicolumn{11}{|c|}{ Null: unit root (assumes individual unit root process) } \\
\hline IPS & 0.47 & 0.96 & 1.56 & -0.57 & $-1.95^{*}$ & 0.72 & -0.27 & -0.49 & -0.23 & -0.48 \\
\hline ADF & 2.49 & 1.20 & 0.96 & 5.65 & $10.5^{*}$ & 2.11 & 3.94 & 4.05 & 3.25 & 2.01 \\
\hline PP & 2.69 & 1.19 & 1.42 & 6.25 & $11.1^{*}$ & 2.70 & 4.34 & 4.39 & 3.25 & 2.17 \\
\hline \multicolumn{11}{|c|}{ Null: unit root (assumes common unit root process First difference test) } \\
\hline LLC & $-14.1^{* *}$ & $-16.3^{* *}$ & $-17.1^{* *}$ & $-11.2^{* *}$ & $-18.6^{* *}$ & $-12.7^{* *}$ & -12.36 & $-18.3^{* *}$ & $-16.7^{* *}$ & $-10.6^{* *}$ \\
\hline \multicolumn{11}{|c|}{ Null: unit root (assumes individual unit root process) } \\
\hline IPS & $-16.4^{* *}$ & $-15.9^{* *}$ & $-16.9^{* *}$ & $-9.5^{* *}$ & $-16.3^{* *}$ & $-11.1^{* *}$ & $-13.0^{* *}$ & $-16.7^{* *}$ & $-16.3^{* *}$ & $-12.8^{* *}$ \\
\hline ADF & $118.2^{* *}$ & $162.3^{* *}$ & $170.6^{* *}$ & $79.6^{* *}$ & $167.3^{* *}$ & $97.5^{* *}$ & $119.2^{* *}$ & $171.1^{* *}$ & $166.2^{* *}$ & $103.2^{* *}$ \\
\hline PP & $146.1^{* *}$ & $164.4^{* *}$ & $170.4^{* *}$ & $114.7^{* *}$ & $174.2^{* *}$ & $98.0^{* *}$ & $123.4^{* *}$ & $172.1^{* *}$ & $166.8^{* *}$ & $122.2^{* *}$ \\
\hline
\end{tabular}

From the results in Table 1, it can be deduced that the null hypothesis of the unit-roots for the combined system of the variables cannot be rejected when variables are taken in level (except for Hong Kong). However, we reject this hypothesis when series are in first differences since the test coefficients are significant for all the countries. These results strongly indicate that the variables are non-stationary in level and stationary in first differences. This finding is supported by both the homogenous and heterogeneous unit root tests. Since the variables became stationary after the first difference, we then proceed to establish their long-run relationship. 


\subsection{Multivariate Analysis of Volatility Transmission}

The Bi-variate GARCH model using the Vector Conditional Heteroskedasticity (VECH) technique is stated in Table 2. Volatility transmission from one variable to another is measured by considering the second moment of each of the variables. The VECH estimates report both the within-sample volatility and between variable volatility. From the results, persistence and cross effects connexion is reported for the variables. The $\mathrm{z}$-value for the coefficient of the ARCH terms for EXRT and SPV is significant for most of the countries. This point to the fact that information from the prior period tends to upset the pattern of the volatility of stock prices and exchange rates for each of the countries. The ARCH term for the cross variable is significant (since the $\mathrm{z}$-value of -2.40 is greater than the $5 \%$ critical value of 1.96 in absolute terms) and shows that news from previous periods tends to affect the pattern of interactions between the real exchange rate and stock price volatility.

Table 2. Volatility Transmission Results

\begin{tabular}{|c|c|c|c|c|c|c|c|c|c|c|}
\hline Factor & UK & US & RSA & Nigeria & H. Kong & China & Kenya & Japan & France & Germany \\
\hline \multicolumn{11}{|c|}{ Mean Equation } \\
\hline Constant & -0.01 & 0.00 & 0.01 & $-0.03^{* *}$ & $-0.09^{* *}$ & 0.02 & -0.04 & 0.03 & 0.00 & 0.00 \\
\hline lag exchange rate & $0.98^{* *}$ & $1.00^{* *}$ & $1.00^{* *}$ & $1.01^{* *}$ & $1.04^{* *}$ & $0.99^{* *}$ & $1.01^{* *}$ & $0.99^{*}$ & $0.99^{*}$ & $0.99^{* *}$ \\
\hline Constant & $6.49^{* *}$ & 0.05 & 0.05 & 0.24 & $0.88^{* *}$ & 0.14 & $0.32^{* *}$ & 0.23 & 0.29 & $0.27^{*}$ \\
\hline lag stock price & $-1.19^{* *}$ & $0.99^{* *}$ & $0.99^{* *}$ & $0.96^{* *}$ & $0.96^{* *}$ & $0.97^{* *}$ & $0.95^{* *}$ & $0.97^{*}$ & $0.96^{*}$ & $0.96^{* *}$ \\
\hline \multicolumn{11}{|c|}{ Relationships } \\
\hline $\begin{array}{l}\text { Exchange rate } \\
\text { constant }\end{array}$ & $0.001^{*}$ & $0.001^{*}$ & 0.00 & 0.00 & 0.00 & 0.00 & $0.001^{*}$ & 0.00 & 0.00 & 0.00 \\
\hline $\begin{array}{l}\text { Stock price volatility } \\
\text { constant }\end{array}$ & $0.00^{*}$ & 0.00 & $0.01^{* *}$ & 0.00 & 0.00 & $0.001^{*}$ & 0.00 & 0.00 & 0.00 & 0.00 \\
\hline EXRT ARCH term & $0.34^{* *}$ & $0.32^{*}$ & 0.02 & $4.37^{* *}$ & $1.68^{* *}$ & $0.23^{*}$ & $0.54^{* *}$ & 0.09 & 0.07 & 0.06 \\
\hline Cross ARCH term & $0.29^{* *}$ & 0.12 & 0.01 & $0.26^{* *}$ & 0.18 & $0.16^{*}$ & 0.25 & $0.16^{*}$ & $0.10^{* *}$ & $0.12^{* *}$ \\
\hline SPV ARCH term & $0.89^{* *}$ & $0.18^{* *}$ & $0.19^{*}$ & $0.37^{*}$ & 0.16 & $0.27^{*}$ & $0.43^{*}$ & 0.15 & $0.18^{*}$ & $0.19^{* *}$ \\
\hline $\begin{array}{l}\text { Persistence in } \\
\text { exchange rate }\end{array}$ & 0.04 & -0.10 & $0.86^{* *}$ & $0.32^{*}$ & $0.29^{* *}$ & $0.76^{* *}$ & $0.48^{* *}$ & 0.51 & $0.84^{* *}$ & $0.83^{* *}$ \\
\hline $\begin{array}{l}\text { Spillovers of stock } \\
\text { price volatility into } \\
\text { exchange rate }\end{array}$ & $0.39^{* *}$ & $0.60^{*}$ & $1.0^{* *}$ & $0.35^{* *}$ & $0.55^{*}$ & $0.73^{* *}$ & 0.58 & -0.03 & $0.85^{* *}$ & $0.81^{* *}$ \\
\hline $\begin{array}{l}\text { Persistence in stock } \\
\text { price volatility }\end{array}$ & 0.04 & $0.78^{* *}$ & 0.03 & $0.81^{* *}$ & $0.70^{* *}$ & $0.57^{* *}$ & $0.50^{* *}$ & $0.70^{* *}$ & $0.77^{* *}$ & $0.76^{* *}$ \\
\hline R-sq. & 0.95 & 0.95 & 0.97 & 0.92 & 0.82 & 0.99 & 0.95 & 0.97 & 0.97 & 0.97 \\
\hline \multirow[t]{2}{*}{ Adj. R-sq. } & 0.95 & 0.95 & 0.97 & 0.92 & 0.82 & 0.99 & 0.95 & 0.97 & 0.97 & 0.97 \\
\hline & 0.02 & 0.02 & 0.04 & 0.02 & 0.00 & 0.01 & 0.03 & 0.02 & 0.02 & 0.02 \\
\hline D.W. stat. & 1.39 & 1.74 & 1.97 & 1.67 & 1.63 & 1.75 & 1.67 & 1.70 & 1.77 & 1.75 \\
\hline
\end{tabular}

The GARCH show persistence in volatility transmission of individual variables across the various markets with spillover effects passing the significance test at $5 \%$ and $1 \%$ level having the $z$-value of 7.5. This is greater than the $1 \%$ critical value of 2.57 . The results show that stock prices and exchange rates for the countries studied are inextricably linked. Thus, while stock price volatility has a direct negative impact on the real exchange rate, the volatility also has a stimulating impact on real exchange rate fluctuations for the countries.

To further evaluate the transmission of volatility, the study considers the conditional correlations between stock prices and exchange rates for each of the countries. Table 3 , shows the $F$ statistic test that examines the shift in the conditional correlations between the variables arising from the periods of higher volatility. The results show that a significant shift occurred in the conditional correlations of the variances of all the markets except for Kenya, Japan and Hong Kong where the F-value failed the test at a $5 \%$ level. This result indicates that higher volatility in stock prices result in a significant structural break and a change in the pattern of movements in the respective exchange rates. 
Table 3: Test of Conditional Correlation Shifts between Exchange rate and Stock Prices

\begin{tabular}{ccc}
\hline Conditional Correlation & F-value & Probability \\
\hline UK & 14.45 & 0.00 \\
US & 6.07 & 0.02 \\
SA & 27.33 & 0.00 \\
Nigeria & 124.5 & 0.00 \\
Hong Kong & 3.70 & 0.06 \\
China & 14.71 & 0.01 \\
Kenya & 3.73 & 0.54 \\
Japan & 0.01 & 0.94 \\
France & 365.1 & 0.00 \\
Germany & 185.9 & 0.00 \\
\hline
\end{tabular}

\section{Conclusions}

The overall implication from the empirical analysis is that politics has effects on the stock market and key macroeconomic indicators such as exchange rate movement. Specifically, the empirical analysis indicated that a significant positive relationship exists between market volatility and exchange rate within the electoral cycles of the studied countries. The transmission of stock market volatility to exchange rate instability during the political cycles was more pronounced for the sub-Saharan Africa countries of Nigeria and South Africa. This perhaps is indicative of weak institutional framework within the financial system.

The study also revealed a significant opportunistic business cycle effect manifesting in a significant shift in the conditional correlations of the variances of all the markets except for Kenya, Japan, and Hong Kong. From this result, we want to strongly believe that a truly independent central bank would not only guarantee political non-interference but also will ensure policy consistency. This is consistent with Eboigbe, (2016). The combination of highly developed markets the USA, (UK, Germany, France -EU members), Hong Kong (almost a-one-party state), etc. with less developed markets (Kenya, Nigeria, Egypt, and RSA-emerging market) for financial analysis present a strong advantage for stakeholder's information-driven decision making. Thus the use of monetary policies is quite ineffective in stimulating output at any particular time. The linkage between the exchange rate and the stock market could, therefore, be explained by the rear economic factors as opposed to these behavioral issues. Stock markets with fluctuations occasioned by behavioral issues could sometimes be catastrophic. Any festering interlinkages between the markets to the extent of easy transmission of the frequent volatilities in the stock market into exchange rates would prove very disastrous.

This study has justified why some known investment decision theories and rules are not sufficient for the present-day global business. Therefore, financial and economic barometers need to integrate the local and international political development for effective and result-driven investment.

Author Contributions: Both authors contributed to the development of all parts of the paper.

Funding: This research received no external funding.

Conflicts of Interest: The authors declare no conflict of interest. 
Hong Kong



South Africa

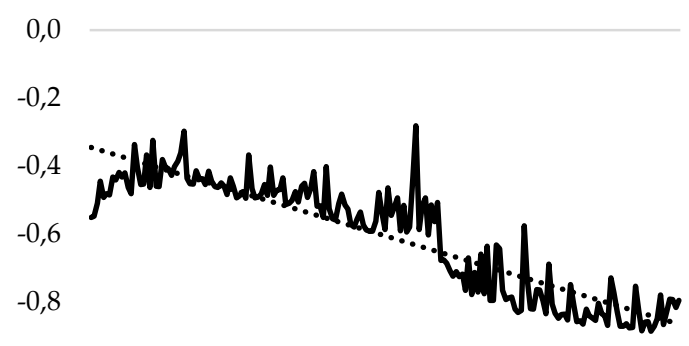

$-1,0$

1,0

Japan



1,00
Kenya

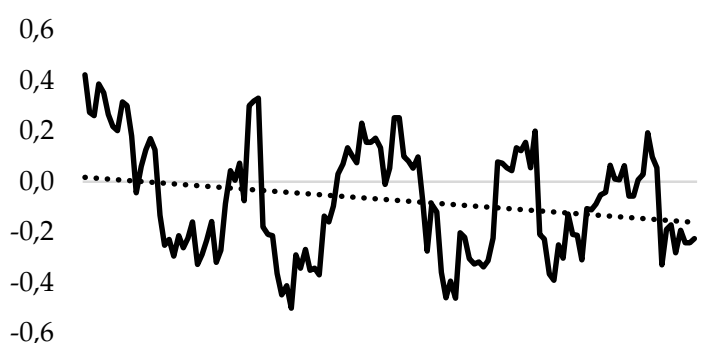

Nigeria



France

0,50

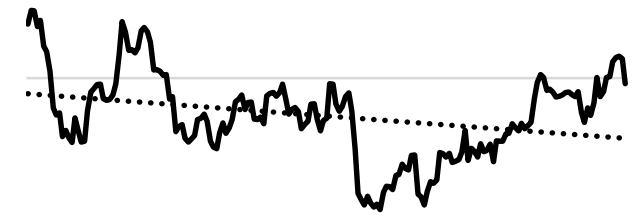

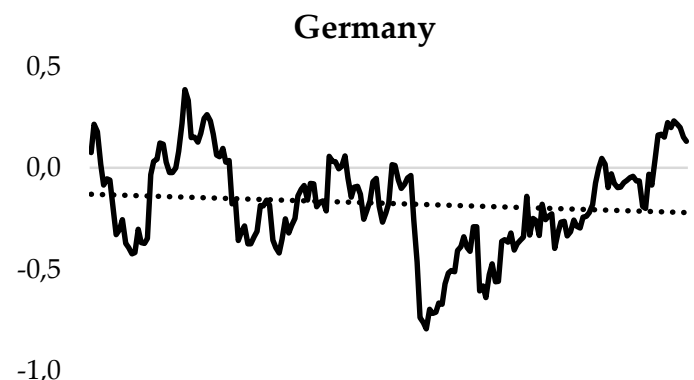

Figure 4: Countries Conditional Correlations Between Stock Price and Exchange Rate Volatility.

\section{References}

Bernhard, W., \& Leblang, D. (1999). Democratic institutions and exchange-rate commitments. International Organization, 53(1), 71-97.

Bernhard, W., \& Leblang, D. (2002). Democratic processes, political risk, and foreign exchange markets, American Journal of Political Science, 46(2), 316-33.

Bialkowski, J., Gottschalk, K., \& Wisniewski, T. P. (2008). Stock market volatility around national elections. Journal of Banking and Finance, 32(9), 1941-1953 
Blomberg, S.B., \& Hess, G.D. (2003). Is the political business cycle for real? Journal of Public Economics, 8, 1091-1121 Bollerslev, T. (1986). Generalized autoregressive conditional heteroscedasticity, Journal of Econometrics, 31,307-327. Bollerslev, T., Baillie, R.T., \& DeGennaro, R. P. (1990). Stock returns and volatility, Journal of Financial and Quantitative Analysis, 25, 203-214.

Boutchkova, M., Doshi, H., Durnev, A., \& Molchanov, A. (2012). Precarious politics and return volatility. Review of Financial Studies 25, 1111-1154.

Cermeno, R., Grier, R., \& Grier, K. (2010). Elections, exchange rates, and reform in Latin America. Journal of Development Economics,92, 166-174

Clark, P.B. (1973). Uncertainty, exchange risk, and the level of international trade, Economic Inquiry, 11(3), 302313

Clark, W.R. (2002). Partisan and electoral motivations and the choice of monetary institutions under fully mobile capital. International Organization, 56(4), 725-749.

Clark, W.R., \& Hallerberg, M. (2002). Mobile capital, domestic institutions, and electorally induced monetary and fiscal policy. American Political Science Review, 94(2), 323-346.

Dalsgaard, T., Elmeskov, J., \& Park, C.Y. (2002). Ongoing changes in the business cycle: Evidence and causes. OECD Economics Department Working Papers, 208.

Eboigbe, S.U. (2016). Political Events, Capital Markets and Economic Performances of selected Countries, Ph.D. Thesis, University of Benin, Nigeria

Engle, R. F. (1982). Autoregressive conditional heteroskedasticity with estimates of the variance of U.K. Inflation, Econometrica, 50, 987-1008.

Frankel, J. A., Schmukler, S.L., \& Serven, L. (2002). Global transmission of interest rates: monetary independence and currency regime. NBER Working Paper, 8828.

Fratzscher, M., \& Stracca, L. (2009). The Political economy under monetary union: Has the Euro made a difference? Economic Policy, 24(58), 307-348

Fratzscher, M., \& Stracca, L. (2009). Does it pay to have the Euro? Italy's politics and financial markets under the Lira and Euro. ECB working paper series 1064

Frieden, J., Ghezzi, P., \& Stein, E. (2001). Politics and exchange rates: A cross-country approach to Latin America. In the currency game: exchange rate politics in Latin America.

Genberg, H., \& Swoboda, A.K. (2005). Exchange rate regimes: Does what countries say matter? IMF Staff Papers, 52, 129-141.

Goonatilake, R., \& Herath, S. (2007). The volatility of the stock market to the news. International Research Journal of Finance and Economics, 11, $53-65$.

Gujarati, D.N, Porter, D.C., \& Gunasekar, S. (2009).Basic Econometrics, 5th edition, Tata McGraw-Hill, New York.

Hays, J. C., Stix, H., \& Freeman, J. F. (2000). Democracy and markets: The case of exchange rates.American Journal of Political Science,44, 449-468.

Hays, J., Freeman, J., \& Nesseth, H. (2003). Exchange rate volatility and democratization in emerging market countries. International Studies Quarterly, 47, 203-228.

Iyoha, M.A., Oyefusi, S.A., \& Oriakhi, D.E. (2003).An introduction to modern macroeconomics, revised edition, Mindex publishing, Nigeria.

Kawai, M., \& Takagi, S. (2001). A proposed strategy for a regional exchange rate arrangement in post-crisis East Asia. Mimeo.

Keefer, P., \& Stasavage, D. (2002). Checks and balances, private information, and the credibility of monetary commitments. International Organization, 56(4), 751-774.

Leblang, D. (2003). To defend or to devalue: The political economy of exchange rate policy. International Studies Quarterly, 23(4), 533-559.

Levy-Yeyati, E., \& Ubide, A. (2000). Crises, contagion, and the closed-end country fund puzzle. IMF Staff Papers 47, 5489.

Loayza, N., Lopez, H., \& Ubide, A. (2001). Co-movements and Sectoral Interdependence: Evidence for Latin America, East Asia, and Europe. IMF Staff Papers 48, 367-395.

Nimkhunthod, W. (2007). An impact of political events on the stock exchange of Thailand, Thammasat University, Bangkok, Thailand

Mackinlay, A.C. (1997). Event studies in economics and finance, Journal of Economic Literature, 35, 13-39. 
Mensi, W., Beljid, M., Boubaker, A., \& Managi, S.(2013). Correlations and volatility spillovers across commodity and stock markets: Linking energies, food, and gold, Economic Modelling, 32, 15-22

Opare, A. (2012). Effects of general elections on the return and volatility of stocks: The evidence from Europe, Catholic University of Milan, Working Paper 224033.

Riaz, Y., \& Ghulzar, M.K. (2015).Political spectrum in stock returns: Evidence from Karachi stock exchange, National University of Science and Technology

Robbani, M.G., \& Anantharaman, S. (2002). An economic analysis of the stock market reaction to political events in emerging markets. Second Annual Applied Business and Information Technology Conference, Pittsburgh, Pennsylvania.

Rogoff, K. (1990). Equilibrium political budget cycles. American Economic Review, 80(1), 21-26.

Sammo, K. S., Yunjong, W. Y., \& Yoon, D.R. (2002). Exchange rate co-movements and business cycle synchronization between Japan and Korea. ADB Institute Research Paper Series No. 40.

Sayce, K. (2013). How the election could impact stocks, and why you should ignore it. Money Morning Australia, http://www.money morning.com.au/20130820

Savita, \& Ramesh, A. (2015). Return volatility around national elections: Evidence from India, Social and Behavioural Sciences, 189,163-168

Shambaugh, J. C. (2004). The effect of fixed exchange rates on monetary policy. Quarterly Journal of Economics. 119(1), 301-352.

Simmons, B., \& Hainmueller, J. (2008). Can domestic institutions explain exchange rate regime choice? PSPE working paper, London School of Economics and political sciences, London, UK.

Stasavage, D. (2003). Transparency, democratic accountability, and the economic consequences of monetary institutions. American Journal of Political Science. 47(3), 389-402.

Stein, E. H., \& Streb, J.M. (2004). Elections and the timing of devaluations. Journal of International Economics 63(1), 119-145.

Stein, E.H., Streb, J.M., \& Ghezzi, P. (2005). Real exchange rate cycles around elections. Economics and Politics .17, 297-330.

Von Hagen, J., \& Zhou, J. (2005). De facto and official exchange rate regimes in transition Economies. Economic Systems. 29(2), 256-275.

Wooldridge, J.M. (2001). Applications of Generalized Method of Moments Estimation. Journal of Economic Perspectives, 15(4), $87-100$.

(C) 2020 by the authors. This article is an open-access article distributed under the terms and conditions of the Creative Commons Attribution (CC BY) license (http://creativecommons.org/licenses/by/4.0/). 